\title{
希薄予混合拡散複合火炎の消炎限界近傍の火炎構造*
}

\author{
川波尊幸 ${ }^{* 1}$, 矢作裕司 ${ }^{* 2}$
}

\section{Flame Structure of Lean Premixed and Diffusion Combined Flames near Extinction Limit}

\author{
Takayuki KAWANAMI $^{* 1}$ and Yuji YAHAGI \\ ${ }^{* 1}$ Shibaura Institute of Technology, 3-7-5 , \\ Toyosu , Koto-ku , Tokyo 135-8548, Japan
}

\begin{abstract}
Extinction and flame structure of lean premixed and diffusion combined flames formed in a counter flow are investigated experimentally and numerically. The extinction limits can be divided into two regions. One is a diffusion flame dominant extinction region (DF-DE) in which equivalence ratio of LPF side $\left(\phi_{L}\right)$ at extinction limit is decreasing linearly with increasing fuel concentration of DF side $\left(\chi_{U}\right)$. The other is a lean premixed flame dominant extinction region (LPF-DE) in which effect of $\chi_{U}$ on extinction $\phi_{L}$ is increasing with increasing $\chi_{U}$. In these two regions, the flame structures and its $\phi_{L}$ dependence are different greatly. In the DF-DE, the temperature has symmetrical profile regardless of $\phi_{L}$ and the temperature peak is located near DF. Since DF has higher temperature than LPF, LPF is thermally supported than DF. Temperature gradients between two reaction zones are decreasing with increasing $\phi_{L}$, while laminar burning velocity $\left(S_{L}\right)$ and burnt gas width $\left(W_{B}\right)$ are constant regardless of $\phi_{L}$. On the other hand, in the LPF-DE, the temperature has asymmetrical profile and the temperature peak leans to the LPF side. That is, the temperature gradient of LPF side is very steep compared with the DF side. Since LPF has higher temperature than DF, DF is thermally supported than LPF. Temperature gradients between two reaction zones are constant regardless of $\phi_{L}$, while $S_{L}$ and $W_{B}$ are increasing with increasing $\phi_{L}$.
\end{abstract}

Key Words : Combustion Phenomena, Premixed Combustion, Diffusion Combustion, Extinction, Flame to Flame Interaction, Flame Structure, Counterflow

\section{1. 緒言}

本研究は希薄予混合拡散複合火炎(希薄複合火炎)の消炎限界近傍の火炎構造を対向流場で明らかにする事を目 的とする. 希薄複合火炎とは, 希薄予混合火炎(LPF)およびそこから排出される高温低酸素濃度の燃焼力゙スを酸化 剤とした拡散火炎(DF)を同時に形成させる火炎である。この火炎は希薄予混合気と燃料が衝突した際に形成され， $2 つ の 火$ 火炎が相互に影響を及ぼし合って燃焼している点に特徵がある.

希薄複合火炎は, 燃料と酸化剂の混合割合が一様ではない非均質燃焼場(1) (3)に形成される様々な局所火炎構造の 内の一つであると考える. 図1(a)は非均質燃焼場の局所火炎構造を単純化したモデルである. 干涉する火炎の構造 の組み合わせは様々なものが考えられるが,ここでは, それらの内の4つを取り上げた(図中の A-Aから D-D断面). A-A'断面では，希薄予混合気と燃料流が衝突することにより希薄複合火炎が形成される. B-B'断面では，組成の異 なる希薄予混合気が衝突し，強度の異なる 2 つの LPF が干渉し合って形成される. C-C’断面では，希薄予混合気 と過濃予混合気が衝突し, LPF と過濃予混合火炎(RPF)が形成され, それらの火炎で消費されなかった反応物が DF を形成し，三重の火炎，すなわち Triple Flame を形成する. D-D’断面では，過濃予混合気に酸化剤流が衝突し，予 混合気側に RPF が形成され，その然焼ガス中に含まれる燃料と対向側の酸化剂が反応して DF が形成される過濃

* 原稿受付 2011 年 10 月 29 日

*1 正員, 芝浦工業大学大学院 理工学研究科（干135-8548 東京都江東区豊洲 3-7-5）

*2 正員, 芝浦工業大学 工学部

E-mail: na11104@shibaura-it.ac.jp 


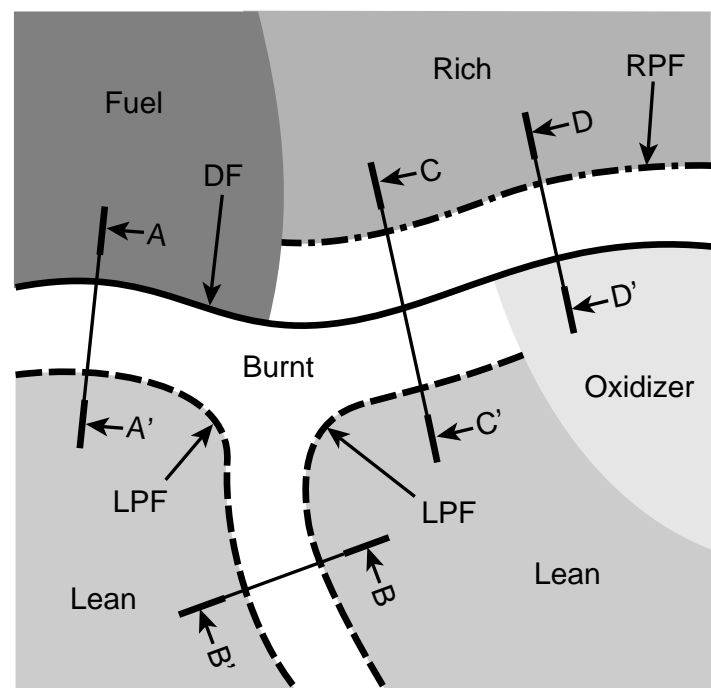

(a) Flamelets structure model.

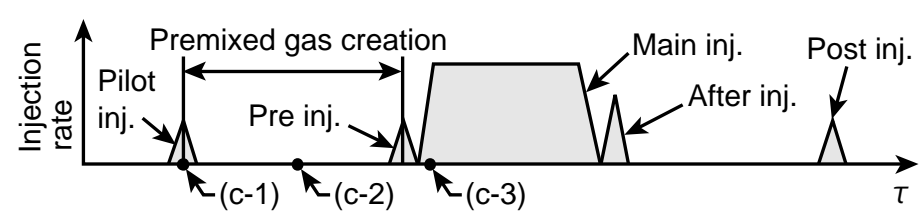

(b) Injection rate and fuel injections timing.

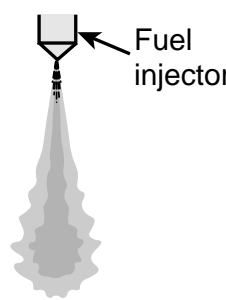

(c-1) Pilot injection.

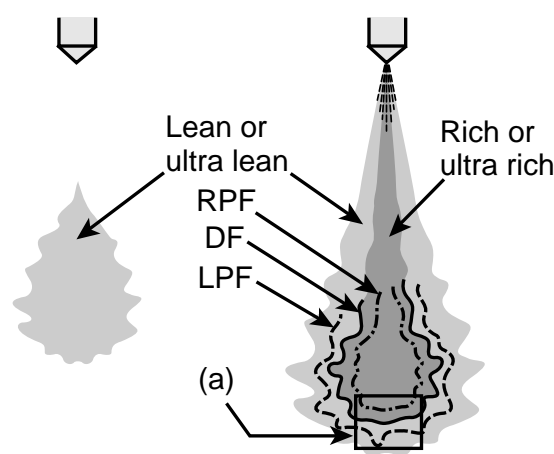

(c-3) Main injection. (c-2) Premixed gas creation.

Fig. 1 Flamelets structure model of heterogeneous combustion in compression ignition engine with multi injection timing common rail ( $\tau$ : Time, Inj.: Injection, LPF: Lean premixed flame, RPF: Rich premixed flame, DF: Diffusion flame).

予混合拡散複合火炎となる. 非均質燃焼場では, 以上に述べた 4 つの複合火炎モデルが形成されていると考えられ る. 図1(a)のモデルが適用できる実用燃焼器は様々あるが, その一つとしてマルチ噴射型のコモンレール式圧縮着 火機関を取り上げた ${ }^{(4)}$. 図 1(b)は上記の機関の噴射時期と燃料噴射率のモデル図である. 図 1(c-1)から(c-3)は図 1(b) に示した各時点における筒内の様子を示している. まず，少量の燃料をパイロット噴射し(図 1(c-1)), 筒内に希薄 予混合気を形成する(図 1(c-2)). その後, 主噴射を行う事で着火し, 燃焼が行われる(図 1(c-3)). 燃料と酸化剤の混 合領域での予混合気は非均質濃度となるため, 図 1(c-3)に示すように LPF, RPF, DF が混在して形成されると考え られる．図1(c-3)中に”(a)”と示した領域に対して図1(a)のモデルが適用できると考える.

希薄複合火炎を再現する場として対向流場が優れている. その理由としては，2つのノズルから噴出される気体 の組成を用いて干渉しあう火炎の強度を個別に制御できる点, 速度勾配の制御が容易である点などの利点があるた めである(5)，層流対向流場は伸張を受けた乱流火炎片のモデル(6) として古くから用いられており，火炎の相互干涉

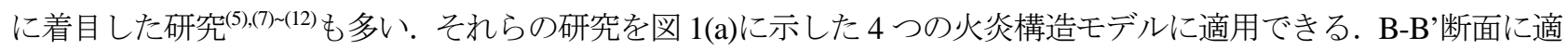
用可能な研究(5),(7),(8) では, 著者ら ${ }^{(8)}$ が火炎構造と消炎限界の関係について検討を加え, 可燃限界以下の当量比の予 混合気も消炎限界に対して影響を与える事, その影響の強さに対してはよどみ点の温度勾配が重要である事を示し

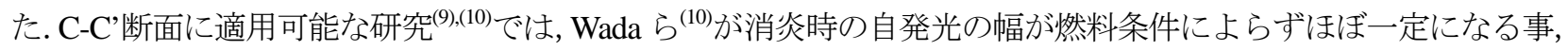
および消炎に対して火炎帯でのCO の生成と消費の釣り合いが重要である事を示した. D-D’断面の研究では, Tanoff

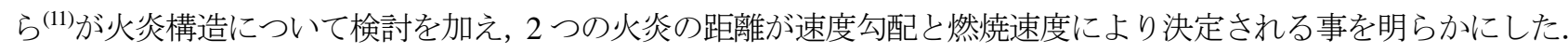

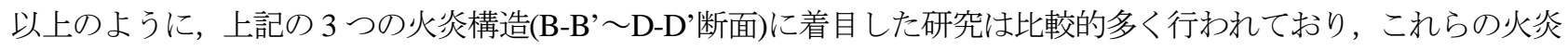
の消炎と火炎構造が密接に関係している事が指摘されている. これに対して A-A'断面の希薄複合火炎に着目した 研究では, Seshadri ら ${ }^{(2)}$ は希薄複合火炎の消炎限界近傍の火炎構造について検討しているが, 主に過濃複合火炎と 拡散火炎との比較を行っており, 希薄複合火炎の消炎限界と火炎構造の関係については議論していない. 図 1(a) の各断面の消炎特性を統合し非均質然焼場の消炎を解明するためには, 希薄複合火炎の消炎と火炎構造の関係を明 らかにする事が必要である。

本研究では, $\mathrm{CH}_{4}$ 空気予混合気と $\mathrm{N}_{2}$ 希釈した $\mathrm{CH}_{4}$ 流を衝突させた対向流場に形成される希薄予混合拡散複合火 炎を対象にして, 消炎限界近傍の火炎構造について実験及び詳細化学反応による数值計算を用いて明らかにする.

\section{2. 実験方法および数値計算方法}

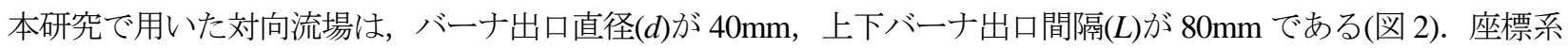




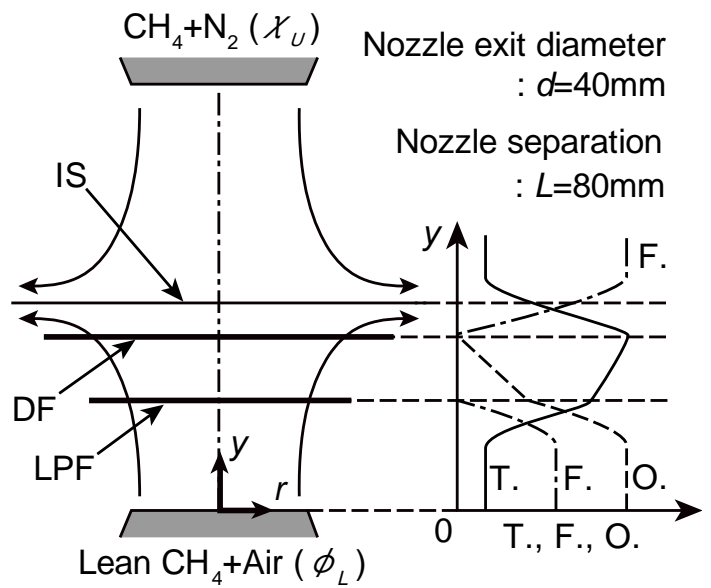

Fig. 2 Schematic of lean premixed and diffusion combined flame formed in the counter flow system (IS : Impinging Surface ).

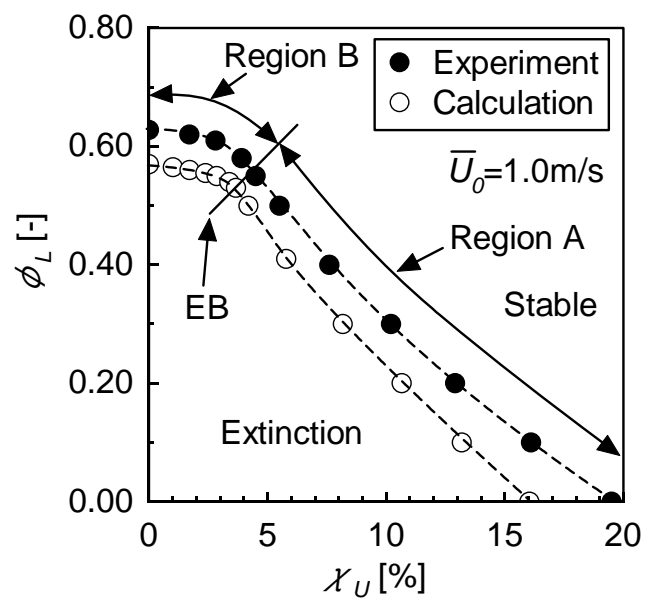

Fig. 3 Extinction limit of laminar combined flame (EB : Extinction Boundary).

は，下方バーナ出口の中心を原点にとり，鉛直上向きに $y$ 軸，半径方向を $r$ 軸とした円筒座標系を用いる. バーナ 出口の断面平均流速 : $\bar{U}_{0}$ は, 双方 $1.0 \mathrm{~m} / \mathrm{s}$ もくは $2.0 \mathrm{~m} / \mathrm{s}$ に設定する. 上方バーナからは $\mathrm{N}_{2}$ 希釈した $\mathrm{CH}_{4}\left(\mathrm{CH}_{4}\right.$ モ ル分率: $\left.\chi_{U}\right)$ を, 下方バーナからは $\mathrm{CH}_{4}$ 空気予混合気(当量比： $\left.\phi_{L}\right)$ をそれぞれ噴出させる. 実験装置には, 外気と のせん断による乱れの発生を防ぐために，ノズル出口と同軸上に環状ノズルを設置し空気を主流の $\bar{U}_{0}$ と同じ速度 で噴出させた. また, 上方のバーナには, 高温の燃焼ガスによる加熱を防止するため, 水冷式の冷却装置と遮熱板 を設置した. 数值計算には, CHEMKINIVおよび OPPDIF を用いた ${ }^{(13)}$. 輸送係数および物性值は GRI-Mech3.0を用 いた ${ }^{(14)}$. 含まれる化学種は 53 種で, 素反応方程式数は 325 式である. 実験では消炎限界, 燃焼ガス幅を測定し, 数值計算では，消炎限界，燃焼ガス幅，層流燃焼速度，火炎位置，温度分布を求めた.

\section{3. 結果および考察}

\section{$3 \cdot 1$ 消炎限界}

図 3 は実験および数值計算により求めた消炎限界である. 図中の黒プロットが実験結果を, 白プロットが計算結 果をそれぞれ示す．実験的には，安定して形成される火炎を $\phi_{L}$ を一定に保ったまま $\chi_{U}$ を徐々に減少させ，両方

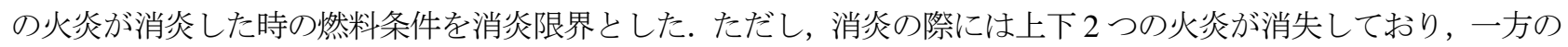
火炎のみが消失する現象は目視では観察できなかった， $x_{U}=0 \%$ の条件だけは $\phi_{L}$ を変化させて消炎限界を測定した. 計算では燃焼による温度上昇が確認される $\phi_{L}, x_{U}$ に燃料条件を設定し， $\phi_{L}$ を一定に保ったまま $\chi_{U}$ を $0.01 \%$ 間隔 で減少させ，燃焼による温度上昇が確認されなくなった条件を消炎と定義し，温度上昇が確認された最も低い $x_{U}$ の值を消炎限界とした. 図中の $\phi_{L}=0$ および $\chi_{U}=0 \%$ 条件では, それぞれ DF もしくは LPF が単体で形成されて いる. 実験および数值計算の結果は同様な傾向を示す. 消炎限界は EB (Extinction Boundary)を境界として消炎に対 する $\phi_{L}$ と $\chi_{U}$ の影響度が異なる Region A と Region B の 2 つの領域に分けられる. Region A では, $\chi_{U}$ の減少に伴 って消炎時の $\phi_{L}$ が増加する.この傾向は $\phi_{L}$ もくは $\chi_{U}$ のどちらか一方を増加させる事で他方を減少させても燃 焼状態が維持できる事，才なわち $\phi_{L}$ と $x_{U}$ に補完関係がある事を示している．また，消炎限界が線形である事は 上記の補完関係が一定である事を意味している. Region B でも $\phi_{L}$ と $x_{U}$ の補完関係は存在するが， $\chi_{U}$ が減少する につれて $\phi_{L}$ の増加率が減少している.つまり， $\chi_{U}$ こる $\phi_{L}$ の補完効果が減少しており，この領域の消炎限界は 主に $\phi_{L}$ にって決定される.

\section{$3 \cdot 2$ 燃焼ガス幅と層流燃焼速度}

燃焼ガス幅 $\left(W_{B}\right)$ とは，上下の流れが衝突する衝突面(Impinging Surface : IS) と LPF の間隔である. DF は燃焼ガス 中の IS 近傍に形成されるため, LPF と DF の間の熱および物質の輸送は燃焼ガス中で行われる. $W_{B}$ を検討する事 で，この輸送現象が起こる領域の空間スケールを特定できる．LPF 位置は伝播性によって変化するため, $W_{B}$ は層 


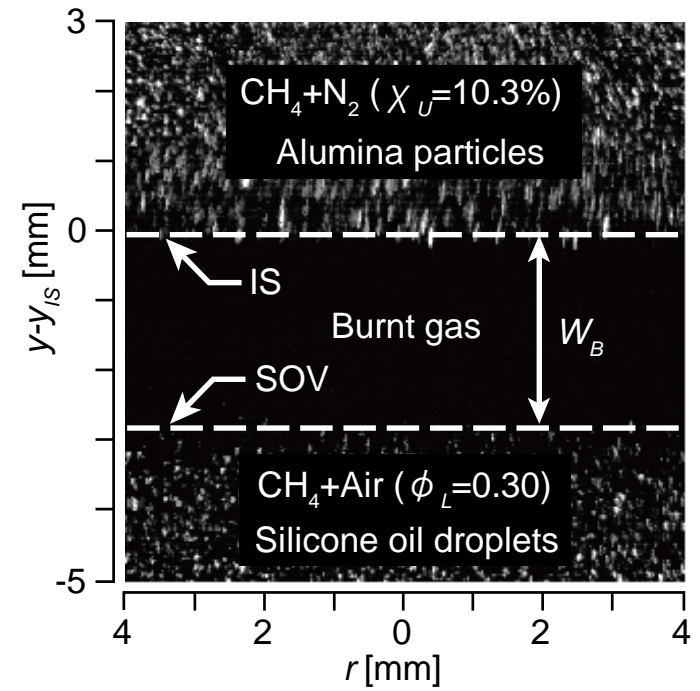

Fig. 4 Visualized burnt gas width $\left(W_{B}\right)$ by a laser tomographic image (SOV:Silicone Oil Vaporized point).

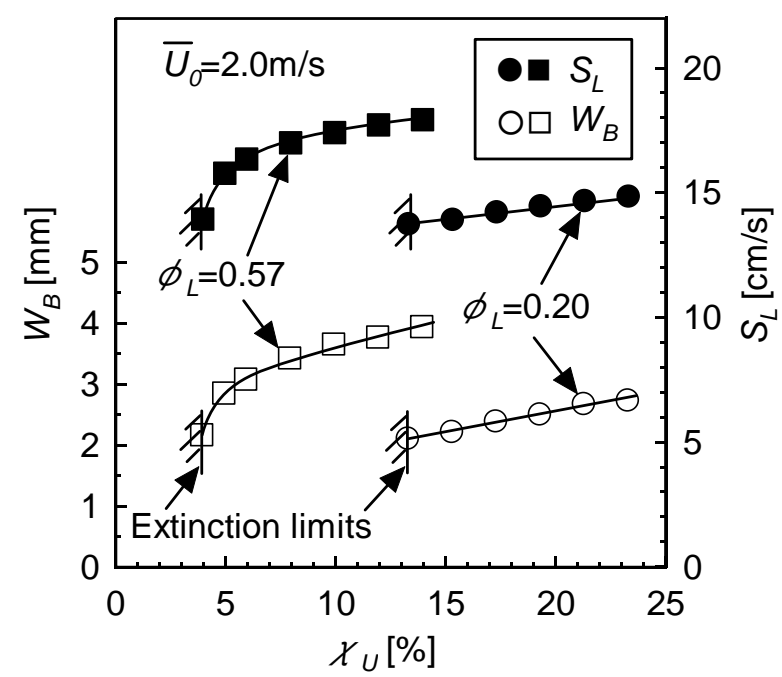

Fig. $6 W_{B}$ and $S_{L}$ from stable flame condition to extinction limit (Calculation).

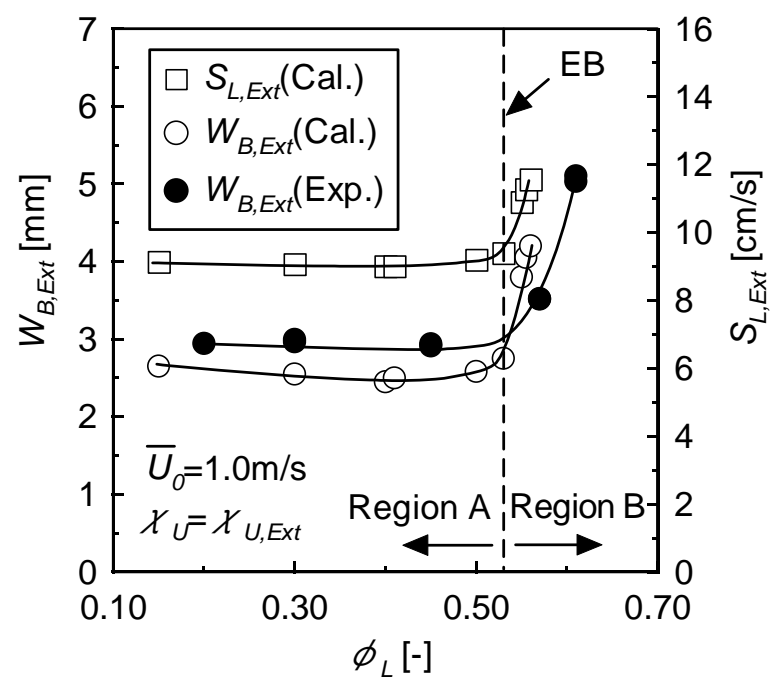

Fig. $5 W_{B}$ and laminar burning velocity $\left(S_{L}\right)$ near extinction limit (Cal.:Calculation, Exp.: Experiment).

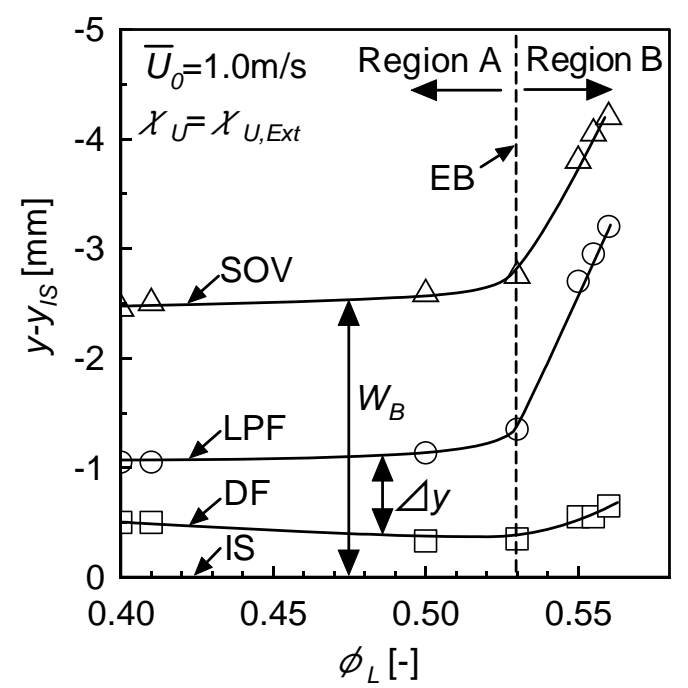

Fig. 7 Flame separation $(\triangle y)$ and $W_{B}$ near extinction limit. $y-y_{I S}=0$ corresponds with IS (Calculation).

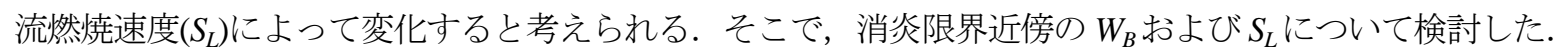

図 4 は $W_{B}$ の定義である. 下方の予混合気流にはシリコンオイル液滴(公称沸点:300 ${ }^{\circ} \mathrm{C}$ )が添加されており, シリコ ンオイルの消失面(Silicone Oil Vaporized point : SOV)から LPF 位置を特定する. 上方の燃料流にはアルミナ粒子(公 称粒径: $1 \mu \mathrm{m}$ )が添加されており IS を特定する. SOV と IS の間隔を $W_{B}$ と定義した. 光源には YAG レーザ(New Wave Research SOLO II -30Hz, 出力:30mJ/pulse)を, 画像の撮影は CCD ビデオカメラ(Megaplus Camera ES1.0, 解像度:1008 $\times 1018$ pix, 検查面積: $20 \times 20 \mathrm{~mm})$ をそれぞれ用いた．数值計算により $W_{B}$ を求める際には，SOV を $300^{\circ} \mathrm{C}$ 等温面， IS をy方向流速が 0 になる位置とそれぞれ定義した. $S_{L}$ は，LPFの予熱帯前面の $y$ 方向流速の極小值と定義した.

図 5 は $\phi_{L}$ の変化に伴う消炎限界近傍の $W_{B}\left(W_{B, E x t}\right)$ と $S_{L}\left(S_{L, E x t}\right)$ の変化である. 図中の黒プロットは実験結果, 白プ ロットは数值計算結果である. $W_{B, E x t}$ は $\phi_{L}$ を固定して $\chi_{U}$ を消炎が発生するまで徐々に減少させた際の消炎直前の $W_{B}$ とした. Region A では, $\phi_{L}$ が変化しても $W_{B, E x t}, S_{L, E x t}$ は共にほぼ一定になる. この結果は当量比によって $S_{L}$ が 変化するという予混合火炎の基本特性と異なっているため, 火炎の相互干涉の影響が加味されていると考えられる. Region B では, $\phi_{L}$ の増加に伴って $W_{B, E x t}$ が著しく増加し, $S_{L . E x t}$ もほぼ同様な増加傾向を示した. Region B での $W_{B, E x t}$ の変化の原因として， $\phi_{L}$ によって $S_{L, E x t}$ が変化し，その結果 LPF 位置が変化したためであると考える. 


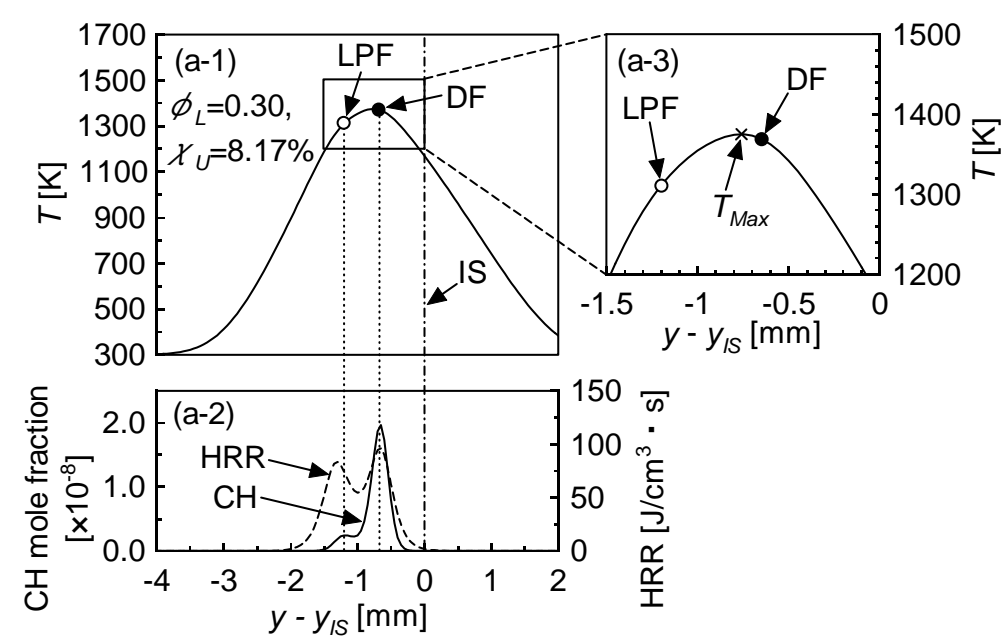

(a) Region A.

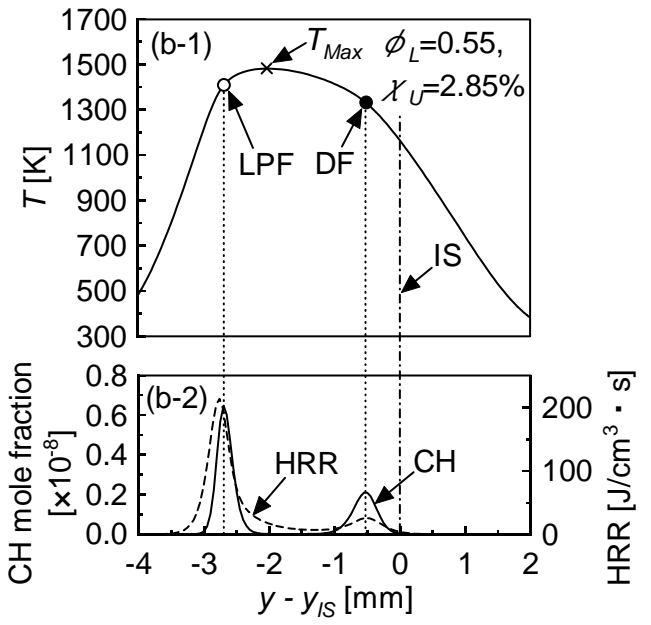

(b) Region B.

Fig. 8 Typical temperature, heat release rate and $\mathrm{CH}$ mole fraction profiles of region A and region B (HRR:Heat Release Rate).

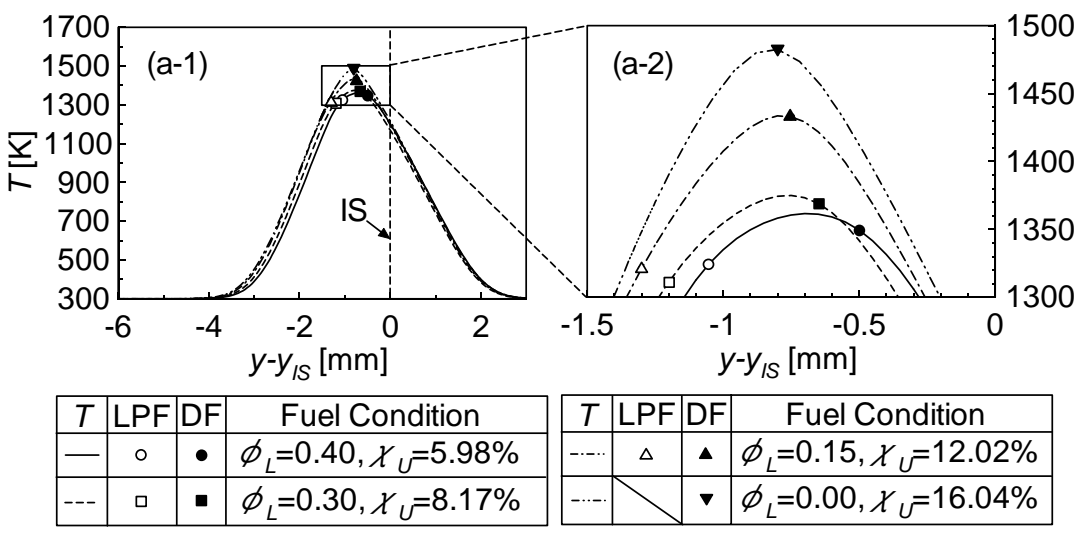

(a) Region A (DF-DE).

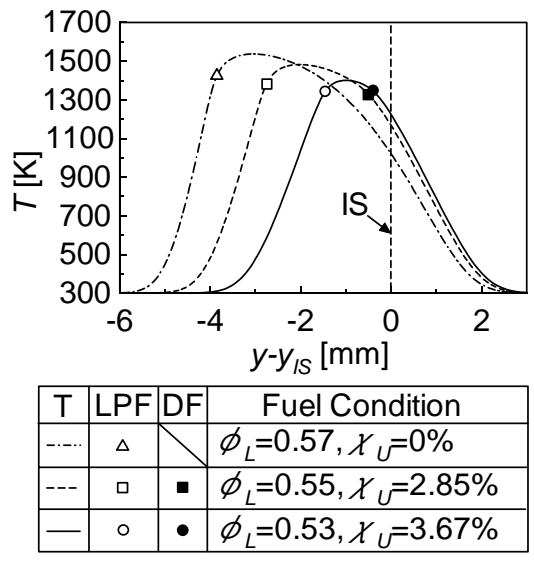

(b) Region B (LPF-DE).

Fig. 9 Temperature profiles near extinction limits (Calculation).

Region A で $\phi_{L}$ によらず $S_{L, E x x}$ が一定になるという図 5 の結果の原因として, 消炎限界に沿って燃料条件を変化さ せるために $\phi_{L}$ の減少に伴って $x_{U}$ を増加させており, この $x_{U}$ の変化が $S_{L}$ に影響を及ぼした可能性を考えた. そこ で， $\phi_{L}$ を固定して $x_{U}$ を消炎限界近傍 $\left(x_{U, E x x}\right)$ まで減少させた際の $W_{B}$ と $S_{L}$ の数值計算結果を図 6 に示寸. 固定し た $\phi_{L}$ の值は Region A の 0.20 と, Region A 中の EB 付近の 0.57 である. $\phi_{L}$ が一定であっても $\chi_{U}$ の減少に伴って $S_{L}$ が減少しており, 複合火炎の $S_{L}$ は $\phi_{L}$ だけでなく $\chi_{U}$ の影響も受ける事が分かる. Region A で $S_{L, E x t}$ が $\phi_{L}$ によら ず一定になった原因は， $\phi_{L}$ の減少による $S_{L}$ の減少を $\chi_{U}$ の増加が補完したためであると考えられる.

\section{$3 \cdot 3$ 燃焼ガス幅と LPF-DF 間隔}

それぞれの火炎に対して CH 濃度が極大となる位置を火炎位置と定義すると，LPF および DF を境界として $W_{B}$ を3つの距離に分割できる. すなわち, SOV と LPF の間隔, LPF およびDF の間隔 $(\Delta y)$, DF と IS の間隔である. これらの距離はそれぞれ，予混合気と LPF，LPF-DF 間，DF と燃料流との輸送現象に関連する． $W_{B}$ と $\Delta y$ の関係 を検討する事で， $W_{B}$ の変化に伴う 3 つの距離の変化の割合を明らかにする事ができる.

図 7 は消炎限界近傍の LPF およびDF の位置, IS およびSOV である. SOV と IS の間隔が $W_{B}$ であり, LPF と DF の間隔が $\Delta y$ である. 縦軸の $y$ - $y_{I S}$ は IS からの相対位置である. $\phi_{L}$ が変化しても $W_{B}$ が一定な Region A では, $\Delta y$ は一定となる．これは， LPF および DF の位置が変化しないためである. $\phi_{L}$ の増加に伴って $W_{B}$ が増加する Region B では， $\triangle y$ は $W_{B}$ と同様に変化する．これは， $W_{B}$ が変化しても，SOV と LPFの間隔およびDF と IS の間 隔はほとんど変化しない事を示している，つまり， $W_{B}$ と $\Delta y$ には正の相関があり， $W_{B}$ を調べる事で $\Delta y$ の傾向を 


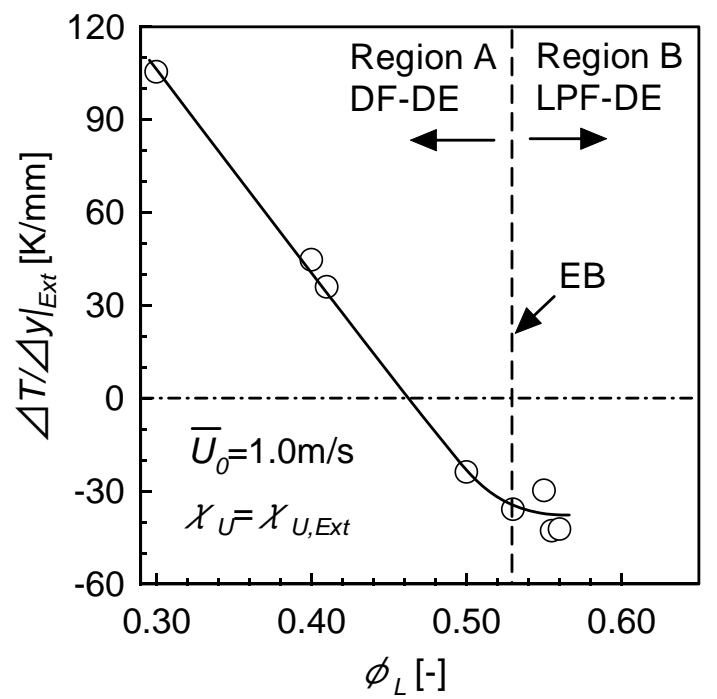

Table 1 Variation of $W_{B, E x t}, S_{L, E x t}$ and $\Delta T /\left.\Delta y\right|_{E x t}$ with increasing $\phi_{L}$.

\begin{tabular}{|c|c|c|}
\hline & $\begin{array}{c}\text { Region A } \\
\text { DF-DE }\end{array}$ & $\begin{array}{c}\text { Region B } \\
\text { LPF-DE }\end{array}$ \\
\hline$w_{B, E x t}$ & $\longrightarrow$ & \\
\hline$S_{L, E x t}$ & $\longrightarrow$ & \\
\hline$\Delta T /\left.\Delta y\right|_{E x t}$ & & $\longrightarrow$ \\
\hline
\end{tabular}

Fig. 10 Temperature gradients between two flames $(\triangle$ $\left.T /\left.\triangle y\right|_{\text {Ext }}\right)$ (Calculation).

明らかにする事ができる.

\section{$3 \cdot 4$ 温度分布}

LPF-DF 間の熱輸送は, 前節で議論した $W_{B}$ と $\Delta y$ に加えて LPF-DF 間の温度勾配や流速などが複合して決定され る. 例えば, Wada ら ${ }^{(10)}$ は対向流中の Triple Flameの火炎間の濃度勾配から化学種輸送を議論している. それを参 考に，希薄複合火炎でも温度勾配から熱輸送の方向および量を考察すると以下のようになる. 図 8 は Region A の 代表的な条件の $\phi_{L}=0.30, \chi_{U}=8.17 \%$ ，および Region B の代表的な条件の $\phi_{L}=0.55, \chi_{U}=2.85 \%$ の数值計算結果を示 す. 図中には温度, 熱発生率, $\mathrm{CH}$ モル分率の分布を示す. 図中の白丸および黒丸プロットは $\mathrm{CH}$ 濃度が極大とな る位置から定義した LPF および DF の位置であり，×プロットは最高温度 $\left(T_{M a x}\right)$ の位置を示す. 図 8(a-1)に示した Region A では, LPF に比べDF の方が高温である. 図 8(a-2)に示したように, 熱発生率およびCH 濃度の極大值も LPF に比べDF の方が高い. LPF-DF 間にも CH は存在しており, その間で発熱反忘も生じている. その結果, 図 8(a-3)に示すように $T_{\text {Max }}$ は LPF-DF 間に存在する. $T_{\text {Max }}$ が LPF-DF 間に存在することから, LPF および DF は $T_{\text {Max }}$ の位置から熱を供給されていると考えられる. したがって, LPFおよび DF の双方の火炎が熱的な補完により存在 する事を示している. LPF-DF 間の温度勾配は $T_{\text {Max }}$ の DF 側より LPF 側の方が急である. LPF 側の温度勾配が急な 事は DF よりも LPFの方が熱的補完の強度が強い事を示している. 他方で, 図 8(b-1)に示した Region B では, DF に比べLPF の方が高温である. 図 8(b-2)に示したように熱発生率およびCH 濃度の極大值も LPF の方が高くなる.

Region A と同様に $T_{M a x}$ は LPF-DF 間に存在するが， $T_{M a x}$ の位置が中心よりも LPF 側に存在している点が異なる. したがって, 温度勾配は $T_{\text {Max }}$ の LPF 側より DF 側の方が急である. DF 側の温度勾配が急な事は LPFよりも DF の 方が熱的補完の強度が強い事を示している。

図 9 は消炎限界に沿って燃料条件を変化させた際の温度分布の変化である. 図 9(a)はRegion A の温度分布であ る. 図 9(a-1)は火炎帯全体を, 図 9(a-2)は最高温度付近を拡大した結果をそれぞれ示す. 図 9(b)は Region B の温度 分布である. ただし，図 9(b)中の実線は EB の条件である. 図の横軸は IS からの距離(y-y IS 一ナ方向(予混合気側), 正の方向が上方バーナ方向(然料流側)を示している. 図中の白プロットはLPF 位置, 黒プ ロットはDF 位置を示している. 図 9(a-1)より, Region A では, $\phi_{L}$ を変化させても温度分布の全体的な形状は変化 しない．温度分布は DF 付近を最高温度としたほぼ対称な形状であり, DF のみを形成した条件(図中の二点鎖線) に類似している. 図 9(a-2)に示した LPF-DF 間の温度分布に着目すると， $\phi_{L}$ が減少し $x_{U}$ が増加するにつれて DF の温度が増加し, LPF-DF 間の温度勾配が増加している. これは, 燃料条件に応じて LPF-DF 間の熱輸送量が変化 している事を示している. DF に比べて LPFの方が熱的補完を強く受けている事から，この領域では複合火炎の消 炎に対してDFが支配的であると考えられる，そのため，Region A を拡散火炎支配消炎(DF Dominant Extinction： 


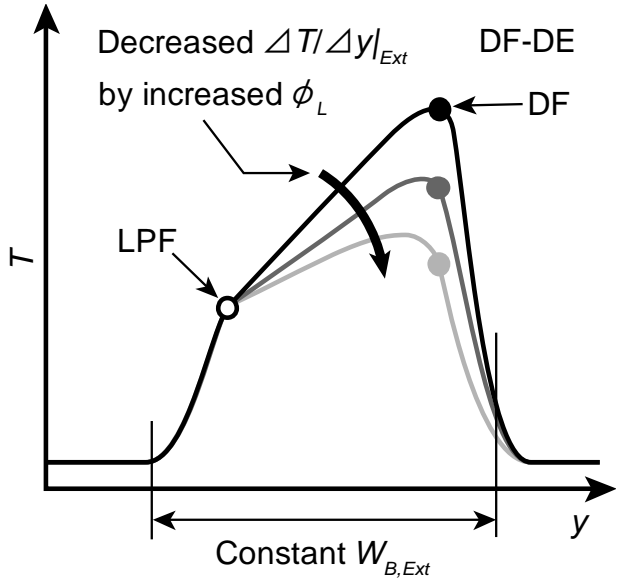

(a) DF-DE model.

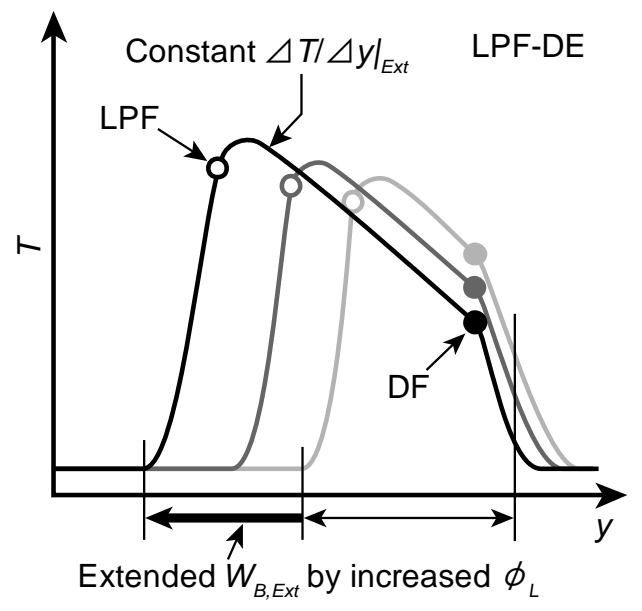

(b) LPF-DE model.

Fig. 11 Flame structure models at extinction limits.

DF-DE)領域と定義する. 図 9(b)に示した Region B では, Region A とは異なり $\phi_{L}$ によって温度分布の全体的な形 状が大きく変化する. 寸なわち， $\phi_{L}$ を増加させるにつれて LPF 位置が予混合気側に移動し, 分布は非対称となる. 分布の形状は LPF のみを形成した条件(図中の鎖線)とほぼ相似である. LPF に比べて DF の方が熱的補完を強く受 けている事から，この領域の複合火炎の消炎に対してLPF が支配的であると考えられる. 従って, Region B は希 薄予混合火炎支配消炎(LPF Dominant Extinction : LPF-DE)領域と定義する.

\section{$3 \cdot 5$ 複合火资の LPF-DF 間の平均温度勾配}

前節では, LPF-DE と DF-DE では LPF と DF が受ける熱的補完の相対強度が異なる点と, DF-DE では $\phi_{L}$ に応じ て LPF-DF 間の温度勾配が変化している点が明らかになった，それらを定量化するために，本節では LPF-DF 間の 平均温度勾配 $(\Delta T / \Delta y)$ につい検討した. 以下の(1)式は $\Delta T / \Delta y$ の定義式である.

$$
\frac{\triangle T}{\Delta y}=\frac{T_{D F}-T_{L P F}}{y_{D F}-y_{L P F}}
$$

ここで， $y_{D F}$ および $y_{L P F}$ は DF および LPF の火炎位置， $T_{D F}$ および $T_{L P F}$ はそれぞれの火炎位置での温度を表して いる. $\Delta T / \Delta y$ の符号は LPF に比べて DF の方が高温な勾配を正とした.

図 10 は消炎限界近傍での $\Delta T / \Delta y\left(\Delta T /\left.\Delta y\right|_{E x t}\right)$ を示寸. $\Delta T /\left.\Delta y\right|_{E x t}$ についても $W_{B, E x t}$ と同様に EB で傾向の変化が見 られるが，その変化は $W_{B, E x t}$ とは逆である. DF-DE では $\Delta T /\left.\Delta y\right|_{E x t}$ は $\phi_{L}$ の増加に伴って線形的に減少する. この結 果は $\phi_{L}$ が高いほど LPF が受ける熱的補完が少ない事を示している. この領域では， $\phi_{L}$ によって $W_{B, E x t}$ が変化しな

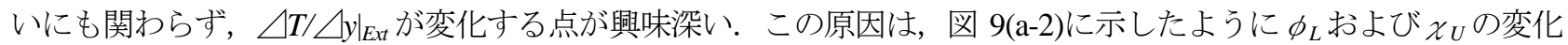
によって LPF と DF の温度差が変化するためである. LPF-DE では $\Delta T /\left.\Delta y\right|_{E x t}$ がほぼ一定になる. $\Delta T /\left.\Delta y\right|_{E x t}$ は負の 值，すなわち LPF の方が高温な勾配である．これは DF が受ける熱的補完が一定である事を示している． $\phi_{L}$ の増 加に伴って $W_{B, E x t}$ が増加するにも関わらず $\Delta T /\left.\Delta y\right|_{E x t}$ が一定になった原因は, LPF と DF の温度差の変化である. す なわち， $\phi_{L}$ の増加に伴う $\mathrm{LPF}$ と DF の温度差の増加が， $W_{B, E x t}$ の増加と釣り合うために $\Delta T /\left.\Delta y\right|_{E x t}$ が一定になった と考えられる.

\section{$3 \cdot 6$ 複合火炎の消炎限界近傍の火炎構造モデル}

$\phi_{L}$ を増加させた際の $W_{B, E x t}, S_{L, E x t}, \Delta T /\left.\Delta y\right|_{E x t}$ の変化を, 増加, 一定, 減少の 3 つに分類すると表 1 のようにな る. $W_{B, E x t}$ および $S_{L, E x t}$ の変化と $\Delta T /\left.\Delta y\right|_{E x t}$ の変化が対照的である. DF-DE では, $W_{B, E x t}$ および $S_{L, E x t}$ は $\phi_{L}$ によらず一 定なのに対して， $\phi_{L}$ の増加に伴って $\Delta T /\left.\Delta y\right|_{E x t}$ は減少する. 一方でLPF-DE では, $\phi_{L}$ の増加に伴って $W_{B, E x t}$ および 
$S_{L, E x t}$ は増加するのに対して, $\Delta T /\left.\Delta y\right|_{E x t}$ は $\phi_{L}$ によらず一定である.

以上の結果をまとめると， $W_{B, E x t}$ と $\Delta T /\left.\Delta y\right|_{E x t}$ に基づいた DF-DE と LPF-DE の消炎限界近傍の火炎構造モデルは 図 11 のようになる. 図11(a)の DF-DE モデルでは， $W_{B, E x t}$ は一定である.この結果は, このモデルの適応領域では 消炎に対して LPF と DF の間の距離が重要である事を示している. 具体的には, LPFに比べて DF の方が高温であ るため，DF に比べて LPF が LPF-DF 間から受ける熱的補完は大きい. 熱的な補完によって， $\phi_{L}$ が希薄可燃限界 以下であっても LPF は燃焼可能になる. ただし, 熱的補完によって $S_{L, E x t}$ は $\phi_{L}$ が変化してもほぼ一定となる. すな わち， $\phi_{L}$ が減少するほど $\Delta T /\left.\triangle y\right|_{E x t}$ が増加するため, LPF-DF 間から LPF への熱輸送量が増加し， $S_{L}$ の減少が補完 されたと考えられる. 図 11(b)に示した LPF-DE モデルでは， $\phi_{L}$ の増加に伴って $W_{B, E x t}$ は増加する. その主な原因 は $\phi_{L}$ による $S_{L, E x t}$ の変化である. DF に比べて LPF の方が高温であるため, LPF に比べて DF が LPF-DF 間から受 ける熱的補完は大きい，その結果，DF は単独では燃焼できない $\chi_{U}$ でも燃焼可能になる．従って， $\Delta T /\left.\Delta y\right|_{\text {Ext }}$ が一 定であるという結果はこのモデルの複合火炎の消炎機構に対してLPF-DF 間から LPFおよびDFへの熱輸送量が重 要である事を示している.

\section{4. 結 論}

希薄予混合火炎(LPF) と拡散火炎(DF)から構成される希薄予混合拡散複合火炎(複合火炎)を層流対向流場を用い て形成した．その消炎限界近傍の火炎構造について検討した結果，以下の事項が明らかになった。

複合火炎の消炎限界は 2 つの領域に分けられる。一方は DF 側の燃料濃度 $\left(x_{U}\right)$ の増加による LPF 側の当量比 $\left(\phi_{L}\right)$ の減少率が一定な拡散火炎支配消炎(DF-DE)領域であり, 他方は $\chi_{U}$ が増加するほど $\phi_{L}$ の減少率が増加する希 薄予混合火炎支配消炎(LPF-DE)領域である.

DF-DE 領域と LPF-DE 領域の火炎構造とその $\phi_{L}$ 依存性には以下のような相違点がある. DF-DE 領域では, DF 付近を最高温度とした対称な温度分布であり， $\phi_{L}$ を変化させても対称性は保たれる. LPF に比べて DF の方が高 温であるため, LPF は LPF-DF 間からの熱的な補完によって維持されている． $\phi_{L}$ が増加するほど LPF-DF 間の温 度勾配は減少するのに対して, 層流燃焼速度と燃焼ガス幅は変化しない. LPF-DE 領域では, LPF 付近を最高温度 とした燃料側に比べ予混合気側の温度勾配が急な非対称な温度分布である. DF に比べて LPF の方が高温であるた め, DF は LPF-DF 間からの熱的な補完によって維持されている． $\phi_{L}$ にっって LPF-DF 間の温度勾配は変化しない のに対して，層流燃焼速度と燃焼ガス幅は $\phi_{L}$ が増加するほど増加する.

本研究に協力してくれた芝浦工業大学学生の池田淳君に感謝する. 本研究の一部は, 文部科学省科学研究費によ り補助金を受けた。ここに記して感謝の意を表す。

\section{文献}

(1) Takagi, Y., “A New Era in Spark-Ignition Engines Featuring High-Pressure Direct Injection”, Proceedings of the Combustion Institute, Vol.27 (1998), pp.2055-2068.

(2) Haworth, D.C., Blint, R.J., Cuenot, B., and Poinsot, T.J., "Numerical Simulation of Turbulent Propane-Air Combustion with Nonhomogeneous Reactants”, Combustion and Flame, Vol.121 (2000), pp.395-417.

(3) Jimenez, C., Cuenot, B. and Poinsot, T. and Haworth, D., "Numerical Simulation and Modeling for Lean Stratified Propane-Air Flames", Combustion and Flame, Vol.128 (2002), pp.1-21.

(4) Bizon, K., Continillo, G., Leistner, K.C., Mancaruso, E., and Vaglieco, B.M., "POD-Based Analysis of Cycle-to-Cycle Variations in an Optically Accessible Diesel Engine”, Proceedings of the Combustion Institute, Vol.32 (2009), pp.2809-2816.

(5) 矢作裕司, 竹内正雄, “対向流中に形成される超希薄予混合火炎の消炎と構造”, 日本機械学会論文集 B 編, Vol. 65, No. 631 (1999), pp.1108-1114.

(6) Peters, N., "Laminar Flamelet Concept in Turbulent Combustion”, Proceedings of the Combustion Institute, Vol.21 (1985), pp.1231-1250.

(7) Sohrab, S.H., Ye, Z.Y., Law, C.K., "An Experimental Investigation on Flame Interaction and The Existence of Negative Flame Speeds”, Proceedings of the Combustion Institute, Vol.20 (1985), pp.1957-1965. 
(8) 浜津邦仁，矢作裕司，竹内正雄，“超希薄予混合気が希薄予混合火炎の消炎に与える影響”，日本機械学会論文集 B 編, Vol. 67, No. 656 (2001), pp.1058-1064.

(9) Lockett, R.D., Boulanger, B., Harding, S.C., and Greenhalgh, D.A., "The Structure and Stability of the Laminar Counter-flow Partially Premixed Methane/Air Triple Flame”, Combustion and Flame, Vol.119 (1999), pp.109-120.

(10) Wada, T., Mizomoto, M., Yokomori, T., and Peters, N., "Extinction of Methane/Air Counterflow Partially Premixed Flames”, Proceedings of the Combustion Institute, Vol.32 (2009), pp.1075-1082.

(11) Tanoff, M.A., Smooke, M.D., Osborne, R.J., Brown, T.M., and Pitz, R.W., "The Sensitive Structure of Partially Premixed Methane-Air vs Air Counterflow Flames”, Proceedings of the Combustion Institute, Vol.26 (1996), pp.1121-1128.

(12) Seshadri, K., and Bai, X.S., "Rate-Ratio Asymptotic Analysis of the Structure and Extinction of Partially Premixed Flames", Proceedings of the Combustion Institute, Vol.31 (2007), pp.1181-1188.

(13) Andrew E. Lutz, Robert J. Kee, Joseph F. Grcar and Fran M. Rupley, “OPPDIF: a FORTRAN Program for Computing Opposed-Flow Diffusion Flames”, Sandia National Laboratories Report, No. SAND96-8243 (1997).

(14) Frenklach, M., Bowman, T., Smith, G., and Gardiner, B., “GRI-Mech 3.0”, GRI-Mech Home Page, http://www.me.berkeley.edu/gri_mech/ (accessed 2012-03-10). 